\title{
correupondence
}

\section{"THE ALTERNATIVES IN VIETNAM"}

San Francisco, Cal. Sir: Surely many people who feel that we must pursue something more than a mere clash of power blocs in waging the cold war, that we must reflect the commitments of our society to the dignity of the individual and to social justice, are as appalled as I am by recent developments in South Vietnam. "The Alternatives in Vietnam," worldoiew, Sept.). I am not taking the occasion to wring my hands over this disaster or over the melancholy alternatives now facing the State Department, or rather us all, but to make a few concrete observations,

In the New York Times (Western Edition) for Saturday, August 24, 1963, David Halberstam writing from Saigon indicates by chapter and verse that not only the broad outlines but the narrow details of the Nhu putsch were widely available to correspondents and to lower echelon United States diplomatic and military personnel, well in advance of its actual date. The Halberstam story has the obvious ring of truth, because of its clear internal consistency, because of later formal and semi-formal confirmations of large parts of it from Washington, and because it plainly fits the pattern. Mr. Halberstam goes on to make the point that even the junior personnel who obtained information about the situation from their Vietnamese counterparts were unable to reach top level diplomatic officials in time and in any perstam sive mamer, and this because the top echelons preferred to listen only to the very top leadership of the country and accept their "line." This is a thing which bothers me more deeply, perhaps, than any other aspect of this disaster.

For a year or more, perhaps for five years, any. one who would sit in a place as remote from these concerns as San Francisco and who would be willing merely to read or listen could have learned from responsible lay publications, such as Harper's or the New York Times, that under the name of anti-communism, and under the banner of Amcrican protection, the vilest public repression was being maintained by the ruling powers of Vietnam. It was also easy to sec from these souxces that the situation was getting worse and was headed for an inevitable showdown. This required no expert knowledge or clairvoyance. One would naturally assume that our large staffs in Saigon and elsewhere would maintain their contacts with the various political elements in that American-subsidized country (as they did) and that as a result of these contacts there would be ample intelligence and opportunity to evaluate trends (as there was, see Haberstam). One would further assume that all this effort had a purpose, mamely, that the information and evaluation would filter up to the decision-making level. This scems to be in error, or in any event if it reached that level, the material seems not to have been signifjeantly regarded. The result is that now we stand with egg on our faces, frantically looking for some local soldiers to counter-putsch and thus rescue us from our civilian proteges.

It was not very. long ago that an administration was in power in Washington, and particularly in the State Department, which seemed to many thoughtful citizens to regard fervent avowals of pro-Americanism by the governors of neutrals or of our client states to be the main if not the sole standard for judging their usefulness as allies. Much administration effort las been devoted in the last few years to advise the public that this attitude has changed. A Presidential campaign was fought in part on this issue. The public had come to believe that a broader base of social justice and less adherence to professions of naked love for America had become the desideratum in client rulers. Now we see that, in South Vietnam at any rate, apparently there was no such change. The official friends of America apparently folt that they had full license to suppress all social justice and all standards of elementary fairness and integrity, meanwhile expressing judgments of unparalleled crudity over their own outrages; and it seems to be a fact that top level American policy took them and their perfunctory avowals to the contrary at full face value. This went on untif the American public, and others, stood aghast at the official blindness of our Government.

Of course now there is obvious consternation and hand-wringing in Washington, as well as casting about for a quick and desperate remedy. I an deeply concerned, however, that all this should have become necessary and that we suddenly find ourselves in the present predicament without having listened to our own diplomats and military and quite semingly without being prepared for this rather predictable turn of events. Specifically, how could it happen at this point in time that, again per Halberstam, 
we maintain this large diplomatic and military apparatus for the purpose of seeking and evaluating information, but the information does not reach the top or is not listened to at the top, and why do we have people in the very top positions in such sensitive places as this who will not listen to their own staffs and will not see what all others cannot avoid secing?

I know that there has been a change of ambassadors, and I know that there is now an obvious effort to change policy, but isn't this a year or two or three after it should have happened? And what are the implications of this history for other countries and for our missions there? In short, how could all this happen in such a vulnerable spot at such a late time in the first Kennedy Administration? One is left with a decp-seated feeling that, despite the presence of a number of gifted and broad-gauged men in many high places, the business of our foreign policy is still not being pursued at its higher levels with the candor, social consciousness and rigorous intelligence which it so clearly demands.

Where do these reflections lead? It should be clear by this date that participation in foreign affairs by the public is minimal. Professors can influence their counterparts in the Administration; those with friends in high places may now and then make a personal impact on a reflective mind; and of course massive, broad (and therefore oversimplified) poputar views still set outside limits of the possible. But in day-to-day matters of foreign policy we are entirely in the hands of our public staffs, and it is their failure to perform at the upper levels which seems to be particularly visible in Vietnam.

Thus the fliw is exposed in the area least amenable to correction and most impervious to the concerns of the socicty it serves-bureaucracy. The readers of worldview may be more nearly an inner core of a concerned public, and thus the echo-side of the Government's dialogue with its constituency at these more specific levels. If that is so, I would thirik that the team will have lost the support of its cheering section. This layman and veteran of three CRIA seminars, etc., is ccrtainly disaffected.

Since World $W$ ar II it has almost always been possible to come to terms with major miscalculations in our foreign policy by thinking that responsible liberalism could have done it better, or occasionally that responsible liberalism was the captive of a domestic storm front. But this Nhu stew exposed the same sorry situation in our foreign affairs while as liberal and as responsible a group is in control as is likely to come to the fore in our country's public life in our age.

Thus it is not likely that comfort can be found in any significant internil political opposition. Al. ready the forces of "adjustment" and "accommoda. tion" are at work. It is as if the oft-repeated lesson had nover been heard, that we cannot hold any ground for long by shoring up dictators impervious to the needs of their peoples. Not to mention that this makes a mockery of the social ends of our American revolution, which presumably we had been packing for export.

Where, then, does one turn? For this writer, at this time, no avenue of comfort has opened. It is not just that our friends in Washington have exred: I think the exposed flaw is deeper than mere tactical error, and I fear it is vital. I see in the pattern of this disaster the reflection of a crucial blindness at the upper levels of bureaucracy (not necessarily by sub-secretaries but just below them). This in turn brings the fear that our worldwide posture will be yet more that of a power which is both so preoccupied with the status quo $\rightarrow$ wherever we have a great investment in some foreign situation, which is to say, wherever it is mportant-and so incapable of responding to its own intelligence appraisals that ever more we will associate and be identified with reaction and repression in the world.

Such a meluncholy course is bound, in my opinion, not only to temove the validation from our bisic world policy but also to prevent its meaningfullfulfillment. At least, I would think, this should follow in parts of the world without an indeperident historical commitment to an open society. And such development might be expected to leave its sears on our domestic society, blighting its content.

If the disease has so thoroughly infested the patient as the Vietnam experience secms to indicate, the picture and the outlook are sad indeed.

Kunt W. MeLchoo 